\title{
Potential role of IgG avidity for diagnosing toxoplasmosis
}

\author{
D H M Joynson, R A Payne, B K Rawal
}

\begin{abstract}
Sera from 20 cases of toxoplasmic lymphadenopathy were examined by an enzyme linked immunosorbent assay toxoplasma IgG avidity (ELISA) at two laboratories. The results obtained were largely in agreement and showed that sera from patients with acute infection had low avidity IgG (30\% or less), whereas sera from patients with chronic infection had high avidity IgG $(40 \%$ or more). It is suggested that this type of assay could have a useful complementary role in antenatal testing for toxoplasmosis.
\end{abstract}

The strength of the interaction of antibody with a monovalent antigen or hapten is known as antibody affinity. In diagnostic serology, however, the relevant interaction is usually that between a serum specimen and a multivalent antigen, and the term used to express the strength of this binding is avidity. ${ }^{1}$ Antibody avidity increases with time after antigenic challenge ${ }^{2}$ and measurement of the avidity of virus specific IgG has been used diagnostically to study cases of rubella ${ }^{3-5}$ and hepatitis $\mathrm{C}$ infections. ${ }^{6}$ In the above mentioned studies with rubella it was shown that protein denaturing agents such as guanidine hydrochloride, diethylamine, and urea, will identify an early serological response by disrupting low avidity reactions between rubella antibody and antigen, thereby enabling the distinction between asymptomatic primary rubella and reinfection to be made. This is of particular value in pregnancy, as specific IgM may be found in both situations. ${ }^{7}$

Recently, Hedman et al reported an enzyme-linked immunosorbent assay (ELISA) which measures the antigen binding avidity of toxoplasma specific IgG antibodies, using urea to elute low avidity IgG associated with recent infection. ${ }^{8}$ They suggested that the ELISA could be used to identify pregnancies that are at risk of congenital toxoplasmosis. The establishment of the approximate date of infection is crucial to patient management in suspected cases of congenital toxoplasmosis and we investigated the potential complementary role of an IgG avidity ELISA for achieving this.

\section{Methods}

Sera from twenty cases of toxoplasmic lymphadenopathy were examined in the Toxo- plasma Reference Laboratory, Swansea by the dye test, ${ }^{9}$ and for the presence of specific antitoxoplasma IgM. ${ }^{10}$ These sera were then tested in parallel at the above laboratory and the Oxford Public Health Laboratory for toxoplasma IgG avidity. The sera were sent to the latter laboratory under code. In most cases the time between the onset of illness and taking of the serum sample was known.

The IgG avidity ELISA method used was essentially that described by Hedman et al, ${ }^{8}$ except that the toxoplasma antigen for coating the wells was prepared as previously described $^{11}$ and used at a dilution of 1 in 200, and after differential washing with and without $6 \mathrm{M}$ urea the residual antigen bound IgG was detected with a rabbit anti-human IgG conjugated to horseradish peroxidase (Dako, Copenhagen) at 1 in 20000 and tetramethylbenzidene substrate (TMB, ICN Biomedicals Ltd). The reaction was stopped with $2 \mathrm{M}$ $\mathrm{H}_{2} \mathrm{SO}_{4}$ and absorbances at $450 \mathrm{~nm}$ were measured with a Multiskan MCC spectrophotometer.

Two dilution curves which plotted absorbance against dilution were drawn for each serum sample, one for the toxoplasma antibody washed with urea and the other without. The corresponding end point titres were determined at $50 \%$ of the maximum absorbance value and the ratio of the end point titres was calculated and expressed as a percentage (titre + urea/titre - urea $\times 100$ ).

\section{Results}

Figures 1 and 2 show the extent of the leftward shift of the dilution curve caused by urea

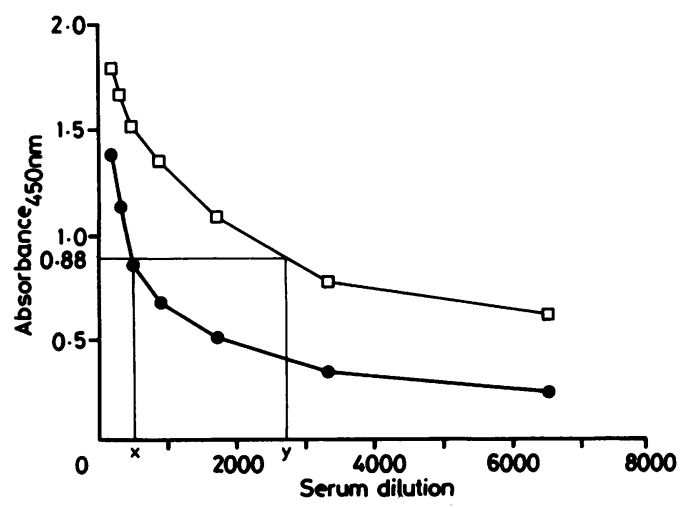

Figure 1 Absorbance curves with and without urea treatment for serum number 1 (duration of lymphadenopathy less than three months). The lower curve represents the sample treated with urea. End point titres used in the calculation of avidity are labelled $x$ and $y$. 


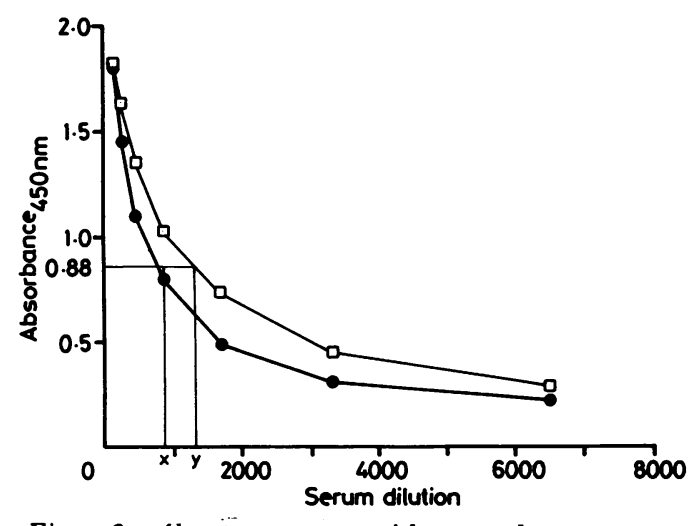

Figure 2 Absorbance curves with ana without urea treatment for serum number 17 (duration of lymphadenopathy more than six months). The lower curve represents the sample treated with urea. End point titres used in the calculation of avidity are labelled $x$ and $y$.

in an acute phase serum and in a serum from a person infected at least one year previously. The IgG avidity results obtained at both laboratories, together with other serological results and details of the onset of illness are shown in the table.

There was broad agreement between the avidity results from the two laboratories. Sera strongly positive for toxoplasma IgM showed avidity levels of $30 \%$ or less; sera negative for IgM had avidity levels of greater than $40 \%$. Most of the sera taken several months after the onset of infection but still containing low concentrations of IgM showed avidity levels of greater than $40 \%$. There did not seem to be any relation between IgG avidity and dye test titres.

\section{Discussion}

Techniques for the measurement of IgG avidity could be applied to a variety of diagnostic problems. IgG avidity can provide confirmatory evidence of an acute infection, distinguish reactivations from primary infections, and allow diagnosis of acute infection to be made from a single serum specimen. It can

Dye test titres, IgM ELISA, and IgG avidity results and date of onset of lymphadenopathy for 20 sera

\begin{tabular}{|c|c|c|c|c|c|}
\hline \multirow{2}{*}{$\begin{array}{l}\text { Serum } \\
\text { number }\end{array}$} & \multirow{2}{*}{$\begin{array}{l}\text { Dye test } \\
\text { titre }\end{array}$} & \multirow[b]{2}{*}{ IgM ELISA } & \multicolumn{2}{|c|}{ IgG avidity (\%) } & \multirow{2}{*}{$\begin{array}{l}\text { Onset of } \\
\text { lymphadenopathy }\end{array}$} \\
\hline & & & Swansea & Oxford & \\
\hline $\begin{array}{r}1 \\
2 \\
3 \\
4 \\
5 \\
6 \\
7 \\
8 \\
9 \\
10 \\
11 \\
12 \\
13 \\
14 \\
15 \\
16 \\
17 \\
18 \\
19 \\
20\end{array}$ & $\begin{array}{r}2048 \\
1024 \\
4096 \\
2048 \\
4096 \\
4096 \\
1024 \\
2048 \\
4096 \\
1024 \\
128 \\
2048 \\
256 \\
1024 \\
256 \\
512 \\
256 \\
1024 \\
1024 \\
1024\end{array}$ & $\begin{array}{l}++ \\
++ \\
++ \\
++ \\
++ \\
++ \\
++ \\
+1- \\
+ \\
+ \\
+ \\
+ \\
+ \\
+1- \\
+1- \\
+ \\
-\end{array}$ & $\begin{array}{l}17 \\
20 \\
21 \\
23 \\
29 \\
29 \\
30 \\
29 \\
39 \\
43 \\
44 \\
44 \\
47 \\
47 \\
51 \\
53 \\
54 \\
55 \\
56 \\
58\end{array}$ & $\begin{array}{l}15 \\
11 \\
18 \\
13 \\
23 \\
14 \\
10 \\
41 \\
21 \\
67 \\
35 \\
43 \\
51 \\
26 \\
46 \\
70 \\
57 \\
46 \\
48 \\
\text { NT }\end{array}$ & $\begin{array}{l}<3 \text { months } \\
<3 \text { months } \\
<3 \text { months } \\
<3 \text { months } \\
<3 \text { months } \\
<3 \text { months } \\
<3 \text { months } \\
>6 \text { months } \\
3-6 \text { months } \\
>6 \text { months } \\
>6 \text { months } \\
>6 \text { months } \\
>6 \text { months } \\
>6 \text { months } \\
\text { Not known } \\
>6 \text { months } \\
>6 \text { months } \\
>6 \text { months } \\
>6 \text { months } \\
>6 \text { months }\end{array}$ \\
\hline
\end{tabular}

++ Strongly positive; + positive; \pm equivocal; - negative; NT not tested. also be applied to the study of antibody avidity following experimental challenge with an antigen or immunisation.

An antibody screening study ${ }^{12}$ using a toxoplasma specific IgM ELISA is being carried out in West Glamorgan and has shown that there are several women with stable dye test titres and low concentrations of specific IgM. Interpretation is impeded by the fact that in some patients toxoplasma specific IgM may be detectable for a year or more after primary infection. To establish whether the antibodies detected in these women indicate acute or past infection it is necessary to examine a further specimen for rising titres. This causes a delay in diagnosis and anxiety for the patient, and it is suggested that this could possibly be avoided by the use of $\operatorname{IgG}$ avidity testing as the results seem to show, in most cases, that an IgG avidity ELISA can distinguish between sera taken at the early stage of the toxoplasma infection from those taken six months after infection. A small range of uncertainty still exists, however, consequently, sequential serum specimens from patients with acute toxoplasmosis, in whom the date of onset of illness is known, are currently being collected in an attempt to assess in detail the correlation between the time after infection and specific IgG avidity maturation in normal subjects. It is hoped that the information obtained will allow this technique to have a complementary role in antenatal testing where knowledge of the approximate date of infection is crucial to patient management. The avidity/time relation for subclasses of $\operatorname{IgG}$ and for $\operatorname{IgM}$ is also being investigated and may further enhance the value of this technique.

1 Roitt IM. Essential immunology. 6th Ed. Oxford: Blackwell Scientific Publications, 1988:60-3.

2 Brown SE, Zuckerman AJ, Howard CR, Steward MW Affinity of antibody responses in man to hepatitis B vaccine determined with synthetic peptides. Lancet 1984 ii: $184-7$.

3 Inouye S, Hasegawa A, Matsuno S, Katow S. Changes in antibody avidity after virus infections: detection by an immunosorbent assay in which a mild protein-denaturing agent is employed. J Clin Microbiol 1984;20:525-9.

4 Rousseau S, Hedman K. Rubella infection and reinfection distinguished by avidity of IgG. Lancet 1988;i:1108-9.

5 Morgan-Capner P, Thomas HIJ. Serological distinction Morgan-Capner P, Thomas HIJ. Serological distinction
between primary rubella and reinfection. Lancet 1988; between

6 Wreghitt TG, Gray JJ, Aloyisus S, Contreras M, Barbara JGJ. Antibody avidity test for recent infection with hepatitis C virus. Lancet 1990;335:789.

7 Morgan-Capner P. In: Mortimer PP, ed. Public Health Virology 12 reports. London: PHLS, 1986:50-62.

8 Hedman K, Lappalainan M, Seppaia E, Makela O. Recent primary toxoplasma infection indicated by a low avidity of specific IgG. $J$ Infect Dis 1989;159:736-40.

9 Fleck DG, Kwantes W. The laboratory diagnosis of toxoplasmosis. In: Public Health Laboratory Service, Monograph Series 13. London: HMSO, 1980.

10 Payne RA, Joynson DHM, Balfour AH, et al. Public Health Laboratory Service enzyme linked immunosorbent assay for detecting Toxoplasma specific IgM antibody. J Clin for detecting Toxoplasm
Pathol 1987;40:276-81.

11 Francis JM, Payne RA, Joynson DHM. Rapid indirect enzyme linked immunosorbent assay (ELISA) for detecting antitoxoplasma IgG: comparison with dye test. J Clin Pathol 1988;41:802-5.

12 Joynson DHM, Payne RA. Screening for toxoplasma in pregnancy. Lancet 1988;ii:795-6. 